\title{
Gender Asymmetry of Entrepreneurial Intentions of Students in Russia and China
}

\author{
Abid Ullah $\mathbb{D} \bowtie$ \\ Ghulam Ishaq Khan Institute of Engineering Sciences and Technology, \\ Topi Swabi, Pakistan \\ \abidullah856@gmail.com
}

\begin{abstract}
Entrepreneurship is now considered to be an urgent solution for handling large pools of young graduates around the world. These crucial situations where universities are creating an excess number of graduates as compared to jobs availability increase the pressure on graduates as well as policy makers and educators. Entrepreneurship in this case does not only handle the burden of the unemployed among the youth but also positively improves the economic development of the country's economy. In becoming entrepreneurs, graduates do not only create jobs for themselves but for other as well and play a vital role in the development of the economy. This paper explains gender-based entrepreneurship intentions amongst students of Russia and China (3 universities in China, 3 in Russia). A questionnaire was developed to find the impact of different behavior factors on male and female students of Russia and China. In terms of methodology, the quantitative technique was used to collect the data. The entrepreneurial spirit is explained after analyzing the data from three universities in each country. The six universities numbering 468 student respondents were analyzed through Statistical Package for the Social Sciences. To find out the association amongst different variables, multiple regression and correlation technique were used. The results also show an association of gender with entrepreneurship in students in both countries. However, in case of Russia male respondents showed higher intention than female respondents. To maintain the same role of male and female members in the society, development suggestions for educators and policy makers are presented.
\end{abstract}

Key words: entrepreneurship; youth entrepreneurship intention; gender; theory of planned behavior.

\section{JEL D71, D81, D91}

\section{Introduction}

The significance of entrepreneurship and its role in economy made it an important topic to be focused on. In the last decade, entrepreneurship has been viewed as a means of transforming the economic condition, productivity improvement and employment creation for many countries. The arguments which make entrepreneurship important in recent years were based on scholars' notion of it as a source of innovation, employment generation, social welfare and increasing productivity [1]. Entrepreneurship creates access to new markets, services and opportunities [Haftendorn \& Salzano, 2].

The importance of entrepreneurship is explained by recent studies and earlier researchers, who also presented the role of entrepreneurship in their work. Later on, in 1985, Peter Drucker described entrepreneurship as an engine of the economy, new jobs creation and source of well-being [3]. It helps the economy to generate a high level of competition through innovation in products, operational process and 
services [4]. Entrepreneurs transform ideas and inventions into economics. Thus, entrepreneurs play an important role in transforming ideas and inventions into economic actions [5].

The above-mentioned role of entrepreneurship in social and economic development of a country keeps the topic open to explore different reasons to become an entrepreneur. The discussion does not end here as there are different factors which play a backbone role in enhancing and predicting entrepreneurial behavior. One of the factors is gender which also influences certain behavior of the human being. As males and females are the same actors in a society participating in its social and economic development. But there is evidence in the literature that males are more entrepreneurial than females. This difference in choosing entrepreneurship as a career also varies from country to country.

In some countries, culture, family pressure, finance, education, availability of resources restrict female or male individuals from performing certain activities. In the present study the following hypothesis were developed based on evidence from literature to find out the entrepreneurial intention of students in Russia and China.

H1: Demographic factor gender is positively associated with entrepreneurship intention among Russian and Chinese students.

H2: Demographic factor gender is positively associated with entrepreneurship intention among Russian and Chinese students.

H3: Demographic factor gender is positively associated with entrepreneurship intention among Russian and Chinese students.

H4: Demographic factor gender is positively associated with entrepreneurship intention among Russian and Chinese students.
The article is divided into four different sections. The introductory part presents the main objective of the study, followed by the previous work on the topic in the literature. In the second section, methodology is explained for the presented study. Finally, the discussion and conclusion part contains the obtained results from the analyzed data and suggestion for educators and policy makers.

\section{Literature Review}

In the majority of entrepreneurship research, researchers also focus on gender as another important variable. Earnings per individual in countries nowadays have shown men are earning more than women.

Some countries in Europe are now ensuring that men and women earn an equal salary income. There can be different reasons but in the case of entrepreneurship, there are female entrepreneurs who according to researchers might be either directly or indirectly involved. In a comparison of different factors it appears that statistically the number of male entrepreneurs is higher than that of female ones $[6,7]$. But due to a change in the environment the number of female entrepreneurs is rising [8].

The fewer number of female entrepreneurs does not show the exact reason for their un-involvement, yet still ambiguous, thus necessitating further research [9]. There were diverse results on gender issues. Some studies like Müller in 2008 and Soetanto, Pribadi, and Widyadana did not reveal any effect of gender on intentions, while Veciana, Aponte, and Urbano in 2005 and Scheiner in 2009 noticed a relationship between gender and entrepreneurial intention [10].

Speaking of intention and theory of planned behavior, there are some studies which found the effect of gender as an antecedent of intention, a direction considered as the predictors of behavior. In 2009, Goethner, Obschonka, Silbereisen, 
and Cantner noticed perceived behavior to be higher in males. Other researchers found another antecedent in higher level, Singh and De Noble in 2003 and Walter and Walter in 2008 found attitude difference [11].

A recent study in the last decade has found males and females become entrepreneurs based on their motivations. [12] Gives importance to cover the gender in their studies. Other studies have found that males are twice as often involved in entrepreneurship as females [13]. In some other places, attitude towards entrepreneurship in male students were found to be higher than in female [14]. There is no clear reason explaining the gender differences in entrepreneurship [15].

The reason for the difference in the number of male entrepreneurs may be that women as compared to men have a lesser degree of social interactivity [16]. Russia and China used in this study targeted university students, especially business and economics, we included gender in the model to find the effect on students' entrepreneurial intention.

According to Ajzen 1991, Theory of Planned Behavior is a very appropriate model of explaining any behavior which necessitates planning like that of entrepreneurship. In the model Theory of Planned Behavior (Figure 1), intention is resolute through 3 attitudinal backgrounds [17].

Attitude towards the behavior shows the point at which a person has a favorable or unfavorable evaluation of a behavior. It is determined by the person's assessment of the projection results of the behavior. This factor looks at the beliefs about the possible outcomes of the behavior (i. e., behavioral beliefs). For example, a person who believes that it is beneficial to perform a given behavior will have a positive attitude toward that behavior, otherwise, will hold a negative attitude.

Subjective norm talks about the social pressures perceived by individuals as to whether to perform the behavior. It recounts to the beliefs that other people are either encouraged or discouraged to carry out a behavior. A person is possibly going to perform a behavior if his or her motivator conform or agree to go in for it. On the other hand, a person will suffer a subjective norm that forces him or her to avoid performing the behavior.

Perceived behavioral control is the opinion of easiness or difficulty in performing a behavior. It recounts to the beliefs about the availability of supports and
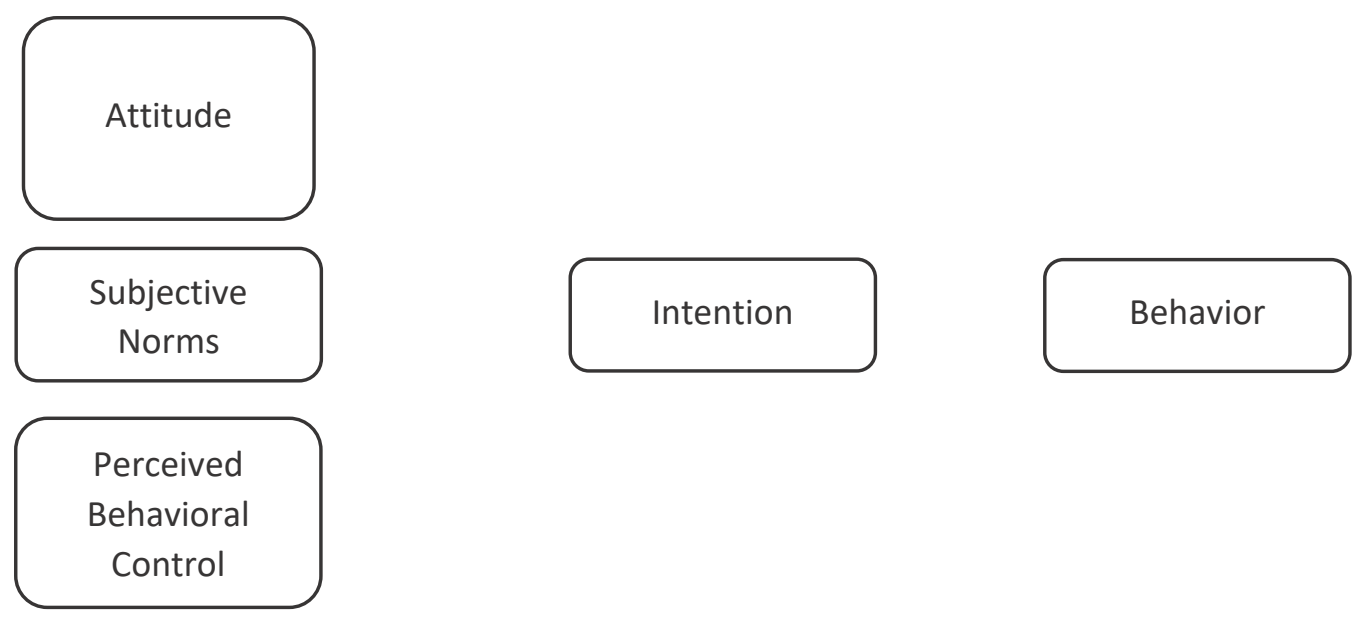

Fig. 1. Theory of Planned Behavior

Рис. 1. Теория запланированного поведения 
resources as well as barriers to performing an entrepreneurial behavior (control beliefs).

\section{Methodology}

The target population was Russian and Chinese business students. The sampling was selected on the basis that they are considered to be potential entrepreneurs while studying business in their bachelor's and master's degree programs.

The research questionnaire was obtained from a review of literature. The questionnaire comprises different variables as explained in the research model. It has two main parts the first part consists of demographics and personal information, while the second part consist of questions on the different variables used in the study. The questions related to the constructs on the theory of planned behavior were obtained from EIQ Liñán \& Chen[18].

This enabled the questionnaires to cover all the research variables. The dependent variable of this research consists of 6 items with entrepreneurial intention mentioned as the main construct. The questionnaires were designed in five-point likert scale ranging from disagreement to agreement, presenting: (1) Strongly disagree; (2) disagree; (3) Neutral; (4) Agree; (5) Strongly agree respectively.

The questionnaires were developed in English, translated into Russian, making it suitable for respondents who cannot speak English [Hambleton, 19]. The translation was done by a professor of English at the linguistics department of Ural Federal University, Russia. In addition, the questionnaire was reviewed by a postgraduate student, together with eminent professors of Economics and Management studies before the pilot test study.

During the pilot study, both English and Russian versions of the questionnaire was distributed among 20 university students in Russia and 25 students in China. The Russian students received hardcopies of the Russian version distributed by the researcher himself, while the Chinese students received the English version of the questionnaire developed in Qualtrics software survey. A Chinese professor in Shanghai University, China received and distributed the online link to the students. The students' responses were recorded using the same medium until the 25 responses were reached.

After collecting the data from the pilot study, a reliability and internal consistency test was conducted through SPSS (version 20) and the results show a Cronbach Alpha value for all the variables ranging from 0.71 to 0.85 as shown in the table 1below. This means that questionnaire was valid and reliable for the study.

In order to analyze the data conveniently and effectively, Statistical software for social sciences (IBM, version 20) was used. Several statistical techniques were

\section{Table 1. Reliability of Statistics}

\section{Таблица 1. Статистические данные о надежности}

\begin{tabular}{l|c|c|c}
\hline \multirow{2}{*}{ Construct Name } & \multirow{2}{*}{ Number of Items } & \multicolumn{2}{c}{ Cronbach's Alpha Value } \\
\cline { 3 - 4 } & & Russian Students & Chinese Students \\
\hline Entrepreneurship intention & 6 & 0.797 & 0.793 \\
Attitude towards entrepreneurship & 6 & 0.847 & 0.831 \\
Perceived behavioral control & 5 & 0.805 & 0.788 \\
Subjective norm & 4 & 0.791 & 0.798 \\
\hline
\end{tabular}


used to analyze the relationship between entrepreneurial intention, attitude towards entrepreneurship, subjective norm, educational and demographics. The statistical techniques to analyze the data including reliability test, descriptive test, multicollinearity tests, independent paired t-test, normality test, Pearson correlation and linear regression were used.

After collecting the data from both countries, the data was filtered to remove the half-filled or missing value questionnaires from the data. During this process, 3 half-filled questionnaires were found in the data from China which were removed to analyze and interpret the data without any missing values. The same method was also applied to the data from Russian students, in which 5 questionnaires were found with missing values which were removed. In both countries' samples, 1 questionnaire was found in Chinese data and 2 were found in Russian data filled by PhD students which were also removed before running it using (Statistical software for social sciences, version 20).

\section{Results}

The demographic profile of the respondents of this study includes gender, age, occupation, level of education and family members who are entrepreneurs in both Russia and China. The specifics of the respondents' demographic profile is presented in table 2 underneath.

\subsection{Descriptive Statistics}

Descriptive statistical test analysis is a measure of central tendency which shortened the data set. Based on the tenacity

\section{Table 2. Demographic characteristics of Russian and Chinese students}

\section{Таблица 2. Демографические характеристики российских и китайских студентов}

\begin{tabular}{|c|c|c|c|c|}
\hline \multirow{2}{*}{ Items } & \multicolumn{2}{|c|}{$\begin{array}{l}\text { Russian } \\
(n=247)\end{array}$} & \multicolumn{2}{|c|}{$\begin{array}{l}\text { Chinese } \\
(n=221)\end{array}$} \\
\hline & $\mathrm{N}$ & $\%$ & $\mathrm{~N}$ & $\%$ \\
\hline $\begin{array}{l}\text { Gender } \\
\text { - Male } \\
\text { - Female }\end{array}$ & $\begin{array}{c}98 \\
149\end{array}$ & $\begin{array}{l}39.7 \\
60.3\end{array}$ & $\begin{array}{c}74 \\
148\end{array}$ & $\begin{array}{l}33.3 \\
66.7\end{array}$ \\
\hline $\begin{array}{l}\text { Age } \\
\qquad \begin{array}{l}\cdot 15-20 \\
\text { - } 20-25 \\
\text { - Above } 25\end{array}\end{array}$ & $\begin{array}{c}65 \\
173 \\
9\end{array}$ & $\begin{array}{c}26.3 \\
70 \\
3.6\end{array}$ & $\begin{array}{c}61 \\
159 \\
2\end{array}$ & $\begin{array}{c}27.5 \\
71.6 \\
0.9\end{array}$ \\
\hline $\begin{array}{l}\text { Occupation } \\
\text { - Full time student } \\
\text { - Employed and student } \\
\text { - Business owner and student }\end{array}$ & $\begin{array}{c}189 \\
58 \\
-\end{array}$ & $\begin{array}{c}76.5 \\
23.5 \\
-\end{array}$ & $\begin{array}{c}218 \\
3 \\
1\end{array}$ & $\begin{array}{c}98.2 \\
1.4 \\
0.5\end{array}$ \\
\hline $\begin{array}{l}\text { Level of education } \\
\text { - Bachelor } \\
\text { - Master }\end{array}$ & $\begin{array}{c}200 \\
47\end{array}$ & $\begin{array}{c}81 \\
19\end{array}$ & $\begin{array}{l}202 \\
20\end{array}$ & $\begin{array}{l}91.5 \\
8.5\end{array}$ \\
\hline $\begin{array}{l}\text { Do you have a family member } w \\
\text { entrepreneur? } \\
\text { - Yes } \\
\text { - No }\end{array}$ & $\begin{array}{r}73 \\
174\end{array}$ & $\begin{array}{r}29.6 \\
70.4 \\
\end{array}$ & $\begin{array}{r}76 \\
145 \\
\end{array}$ & $\begin{array}{l}34.2 \\
65.8\end{array}$ \\
\hline
\end{tabular}


of this empirical research, mean is used in measuring this central tendency so as to exemplify the data set, since it constitutes the basis of the ultimate quantitative analysis of data. An aggregate amount of 221 and 247 students fruitfully completed answering this questionnaire in both China and Russia respectively as shown in Table 3 and 4. The outcome of the Statistical software for social sciences statistical analysis test on the measure of central tendency, particularly the mean test, demonstrate that the students' opinion widely range from one construct to another.

Beside the above, three above-mentioned constructs, the fourth and fifth construct for the Chinese students are perceived behavior control with a mean value of (2.7956) and educational environment with a mean scored of (2.9921). Still in the Russian sample domain, the last two constructs are educational environment with a mean value of (2.4585) and subjective norm registering a mean value of (2.2399).

The subjective norm recorded the uppermost mean in the midst of all the constructs, consist of a mean value of (3.1655) in China, while in Russia the attitude towards entrepreneurship construct recorded the topmost mean value of (2.9380) among all the constructs. This implies that Chinese students' intension towards entrepreneurship will be higher and they are more likely to become entrepreneurs in the future if their intention is influenced by the family, friends, spouses etc., who support their decision to become entrepreneurs. On the other hand, Russian students developed high preference for entrepreneurial jobs, and they will likely become entrepreneurs in the near future.

The attitude towards entrepreneurship with a mean scored of (3.0369) and entrepreneurial intension recording a mean value of (2.8191) emerged as the closest to the topmost constructs for both Chinese and Russian students respectively. Here, this indicates that the Chinese students' perception of becoming entrepreneurs in the future is moderately high whereas the Russian students' intensions of becoming future entrepreneurs are average. The succeeding constructs after the first two is the educational environment for the Chinese student registering a mean value of (2.7988) whereas perceived behavior control with a mean value of (2.4838) for the sample of Russian students. This means that quite a number of Chinese students believed that an entrepreneurial educational environment contributes to their entrepreneurial intensions but the Russian sample indicate a relatively number of students who believed that they have the ability to control their beliefs in order to venture into entrepreneur business.

\section{Table 3. Descriptive statistics for Chinese students}

\section{Таблица 3. Описательная статистика для китайских студентов}

\begin{tabular}{l|c|c|c|c|c|c}
\hline & $\mathrm{N}$ & Minimum & Maximum & Mean & $\begin{array}{c}\text { Standard } \\
\text { Deviation }\end{array}$ & Variance \\
\hline $\begin{array}{l}\text { Entrepreneurship Intention } \\
\begin{array}{l}\text { Perceived Behavioral } \\
\text { Control }\end{array}\end{array}$ & 221 & 1.00 & 5.00 & 2.7988 & .88224 & .778 \\
$\begin{array}{l}\text { Attitude Towards } \\
\text { Entrepreneurship }\end{array}$ & 221 & 1.00 & 5.00 & 2.7956 & .78694 & .619 \\
$\begin{array}{l}\text { Subjective Norm } \\
\text { Valid N (listwise) }\end{array}$ & 221 & 1.00 & 5.00 & 3.1655 & .86923 & .756 \\
\hline
\end{tabular}




\section{Table 4. Descriptive statistics for Russian students}

\section{Таблица 4. Описательная статистика для российских студентов}

\begin{tabular}{l|c|c|c|c|c|c}
\hline & $\mathrm{N}$ & Minimum & Maximum & Mean & $\begin{array}{c}\text { Std. } \\
\text { Deviation }\end{array}$ & Variance \\
\hline $\begin{array}{l}\text { Entrepreneurship Intention } \\
\begin{array}{l}\text { Perceived Behavioral } \\
\text { Control }\end{array}\end{array}$ & 247 & 1.00 & 5.00 & 2.8191 & .79263 & .628 \\
$\begin{array}{l}\text { Attitude Towards } \\
\text { Entrepreneurship }\end{array}$ & 247 & 1.40 & 5.00 & 2.9380 & .86862 & .754 \\
$\begin{array}{l}\text { Subjective Norm } \\
\text { Valid N (listwise) }\end{array}$ & 247 & 1.00 & 5.00 & 2.2399 & .99893 & .998 \\
\hline
\end{tabular}

To check the impact of demographic variables on dependent variable entrepreneurship intention and the construct of (Theory of Planned Behavior) intendent t-test were run; the results as shown below. In an independent t- test we compare two means of two groups to find out the impact of independent variables on dependent variables. In this study a group of students from Russia and China was the target sample. For that, we need to run independent t-test to find out the impact of independent variables on dependent variable. To find out the impact of demographic on dependent variable entrepreneurial intention the test was run for both the sample one by one.

\subsection{Gender}

As earlier explained in the hypothesis developing section, there are different studies which explains different results of connectivity between gender and entrepreneurial intention. In the case of this comparative study of Russian and Chinese students the difference intentions based on the age of the respondents are given in Table 5 and 6.

For Russian students, the impact was found a little in subjective norms. It means that subjective norms can be different in male and female. The significant difference was found in subjective norm (mean $=$ 2.46, $\mathrm{SD}=0.94, \mathrm{p}<0.05$ ) for male decision in Russian students can be affected by the

\section{Table 5. Independent sample t-test for Russian students' sample with gender}

Таблица 5. Т-тест для независимых выборок для русских студентов (образец с гендерными данными)

\begin{tabular}{l|c|c|c|c|c|c}
\hline \multirow{2}{*}{ Variables } & \multicolumn{2}{c|}{$\begin{array}{c}\text { Male } \\
(n=97)\end{array}$} & \multicolumn{2}{c|}{$\begin{array}{c}\text { Female } \\
(n=149)\end{array}$} & \multicolumn{2}{c}{ Sig. } \\
\cline { 2 - 8 } & Mean & SD & Mean & SD & T & Sig \\
\hline Entrepreneurial intention & 2.8244 & .82632 & 2.7221 & .77272 & -0.10 & 0.94 \\
Perceived behavioral control & 2.3844 & .61501 & 2.5492 & .63716 & -202 & 0.066 \\
\hline $\begin{array}{l}\text { Attitude towards } \\
\text { entrepreneurship }\end{array}$ & 2.9286 & .90963 & 2.9442 & .84328 & -206 & 0.891 \\
Subjective norm & 2.4643 & .94841 & 2.0923 & 1.00688 & 2.99 & 0.006 \\
\hline
\end{tabular}

Note: $* \mathrm{p}<0.05, * * \mathrm{p}<0.01$. 
people who are in close circle (e. g. Family, friend, peers, relatives etc). While in the case of overall entrepreneurship intention there was no significant effect found in the sample of Russian students.

However, in the case of Chinese students we see the gender impact on all constructs except university environment. In this way the highest mean value for all construct except educational environment were found in male students. The main dependent variable of entrepreneurship intention was also found in significant relationship with gender of the respondents.

\section{Discussion}

The first attempt of this study was to confirm the applicability of theory of planned behavior in investigating the intention of students in two countries with transition economies. The result from both countries shows different values of the coefficient of determination $\left(\mathrm{R}^{2}\right)$ revealed that $65.3 \%$ for Chinese students and $41.3 \%$ for the Russian students. This result matches the outcomes of previous studies which range from $22.5 \%$ to $62 \%$. The study of Lekovela et al., in 2011 indicate $62 \%$ of variance in developing countries comparison with $59 \%$ in developed countries. Also, the study of Kristiansen and Indarti, in 2004 shows a result of $22.5 \%$ for Norwegian students and $25.9 \%$ for Indonesian [20, 21].

This confirm that theory of planned behavior is applicable in two transition economy countries like China and Russia. In comparing the constructs of theory of planned behavior in both countries, the SPSS test revealed a high significant result for all the constructs adopted for this empirical study.

Based on theory of planned behavior three hypotheses were developed in this study. To test these three hypotheses of Theory of Planned Behavior Pearson's Bivariate Correlation was performed. The three constructs of Theory of Planned Behavior consisted of the attitude towards entrepreneurship, Perceived behavioral control and subjective norm. In the first hypothesis testing attitude towards entrepreneurship scored $\alpha=0.01 ; \mathrm{p}<0.05$, for both samples of the students.

Therefore, it is clear from the results that attitude towards entrepreneurship will influence intention of Russian and Chinese students towards entrepreneurship. This result of the first construct of Theory of Planned Behavior is consistent with the previous studies in the same area $[22,23]$. In their studies, they found out that attitude influence intention towards entrepreneurship.

\begin{tabular}{|c|c|c|c|c|c|c|}
\hline \multirow{2}{*}{ Variables } & \multicolumn{2}{|c|}{$\begin{array}{l}\text { Male } \\
(\mathrm{n}=97)\end{array}$} & \multicolumn{2}{|c|}{$\begin{array}{l}\text { Female } \\
(\mathrm{n}=149)\end{array}$} & \multicolumn{2}{|c|}{ Sig. } \\
\hline & Mean & SD & Mean & SD & $\mathrm{T}$ & Sig \\
\hline Entrepreneurial intention & 2.6734 & .74914 & 2.2128 & .76730 & 4.52 & 0.000 \\
\hline Perceived behavioral control & 3.0479 & .76097 & 2.6712 & .77199 & 3.43 & 0.001 \\
\hline $\begin{array}{l}\text { Attitude towards } \\
\text { entrepreneurship }\end{array}$ & 3.3863 & 1.06266 & 2.9007 & .80423 & 3.61 & 0.001 \\
\hline Subjective norm & 3.4966 & .75113 & 3.0000 & .87918 & 4.27 & 0.001 \\
\hline
\end{tabular}

Note: $* \mathrm{p}<0.05, * * \mathrm{p}<0.01$. 
While performing a certain entrepreneurial activity students do favorable or unfavorable evaluation. In this case for Russian students, the attitude was the lowest in regression analysis to affect their intention towards entrepreneurship with the Standardized regression coefficient $\beta$ value of 0.133 , while for Chinese students it shows the value of $\beta 0.238$ at number second in the three construct of Theory of Planned Behavior. This describes that attitude towards entrepreneurship is one of the variables which affect Russian and Chinese intention towards entrepreneurship. When the attitude towards entrepreneurship among Russian and Chinese students is favorable, they will start their own venture in the future.

Similarly, the second hypothesis results based on the construct of Theory of Planned Behavior which was perceived behavioral control was observed after Pearson correlation here also the same value $\alpha=0.01 ; p<0.05$, was observed for both the sample of students. Standardized regression coefficient $\beta$ value of 0.297 , for Russian students in number second in the construct, while for Chinese students it shows value of $\beta 0.633$ at the highest preference in the three constructs of Theory of Planned Behavior.

Based on theory of planned behavior three hypotheses were developed in this study. To test these three hypotheses of Theory of Planned Behavior Pearson's Bivariate Correlation was performed. The three constructs of Theory of Planned Behavior consist of the attitude towards entrepreneurship, Perceived behavioral control and subjective norm. In the first hypothesis testing attitude towards entrepreneurship scored $\alpha=0.01 ; \mathrm{p}<0.05$, for both samples of the students.

It is therefore clear from the results that the attitude towards entrepreneurship will influence intention of Russian and Chinese students towards entrepreneurship.
This result of the first construct of Theory of Planned Behavior is steady with the previous studies in the same area $[24,25]$. In their studies, they found that attitude influences intention towards entrepreneurship. While performing a certain entrepreneurial activity student do favorable or unfavorable evaluation.

In this case for Russian students, the attitude was the lowest in regression analysis to affect their intention towards entrepreneurship. Standardized regression coefficient $\beta$ value of 0.133 , while for Chinese students it shows value of $\beta 0.238$ at number second in the three construct of Theory of Planned Behavior. This describes that attitude towards entrepreneurship is one of the variables which effect Russian and Chinese intention towards entrepreneurship. When the attitude towards entrepreneurship among Russian and Chinese students is favorable, they will start their own venture in the future.

Similarly, the second hypothesis results based on the construct of Theory of Planned Behavior which was perceived behavioral control was observed after Pearson correlation here also the same value $\alpha=0.01 ; p<0.05$, was observed for both the sample of students. Standardized regression coefficient $\beta$ value of 0.297 , for Russian students in number second in the construct, while for Chinese students it shows value of $\beta 0.633$ at highest preference in the three constructs of Theory of Planned Behavior. The results are consistent with previous studies in the literature of perceived behavioral control is the predictor of entrepreneurship intention [26, 23, 25]. This shows perceived behavioral control will increase 0.297 value for Russian students and 0.633 with a unit value of perceived behavioral control. While perceived behavioral control is the perception of difficulty or easiness to perform entrepreneurial behavior.

Furthermore, for the third construct of Theory of Planned Behavior the 
hypothesis was tested to check the impact of subjective norm and the results of Pearson correlation showed that values of $\alpha=0.01 ; p<0.05$, for both samples of the students. Standardized regression coefficient $\beta$ value of 0.357 , for Russian students in number second in the construct, while for Chinese students it shows value of $\beta 0.181$ at lowest preference in the three constructs of Theory of Planned Behavior) The results of the third construct supported the previous findings in the literature of $[25,23]$. This shows that subjective norms will increase 0.357 value for Russian students and 0.181 with a unit value of subjective norms. The social pressure which an individual perceived, while performing a certain entrepreneurial behavior is called subjective norm.

The independent t-test when was run on the gender there also the impact was found in both countries' samples. For Russian students the entrepreneurial intention in males were little higher than in females. In Russian students sample the impact of gender subjective norm a construct of theory of planned behavior were found significant. In Chinese students sample the gender impact were found significant on all variables except university entrepreneurial environment. This means that in both countries control variable gender has impact on future career decision.

\section{Conclusion}

Entrepreneurship plays an important role in job creation, innovation, economic and social development of a country. Based on the conducted study both countries need to promote entrepreneurship in their societies. Educational institutions may play an important role in providing the same playground to male and female students. In our research results, Russian students showed lower intention to choose entrepreneurship as a career in comparison to Chinese students. Similarly, in gender-based comparison Chinses females showed higher intentions towards entrepreneurship. Entrepreneurship programs, promotion of entrepreneurship in society, adding entrepreneurship to the curricula of education institution may increase the motivation level of the youth in both countries, especially in female students.

The sample size of this study was enough to statistically test the model of theory of planned behavior with certain variables but is not big enough to generalize it on the entire population of two countries. Due to limited resources the research sample size was limited to only 300 students from each country. The total number of female respondents in both countries sample was bigger as compared to male respondents. The sample size is gender biased, therefore future studies should include more male students in order to make the respondents neutral in both genders.

\section{References}

1. Reynolds, P., Hart, M., Mickiewicz, T. (2014). The UK Business Creation Process: The 2013 Panel Study of Entrepreneurial Dynamics Pretest. Foundations and Trends in Entrepreneurship, Vol. 4, 1-43. DOI: 10.13140/RG.2.2.27165.51685.

2. Haftendorn, K., Salzano, C. (2003). Facilitating Youth Entrepreneurship. Part 1: An Analysis of Awareness and Promotion Programmes in Formal and Non-formal Education. SEED Working Paper No. 59. Geneva, Switzerland, International Labour Office, 70 p.

3. Drucker, P. (1985). Innovation and Entrepreneurship. Practice and Principles. London, Heinemann, $27 \mathrm{p}$.

4. Thurik, R., Wennekers, S. (2004). Entrepreneurship, small business and economic growth. Journal of Small Business and Enterprise Development, Vol. 11, No. 1, 140-149. DOI: 10.1108/14626000410519173. 
5. Baumol, W. (2002). The Free-Market Innovation Machine. Princeton, Princeton University Press, 336 p.

6. Minniti, M., Allen, I.E., Langowitz, N. (2005). Global Entrepreneurship Monitor 2005. Report on Women and Entrepreneurship. Babson Park, The Center for Women's Leadership at Babson College, $79 \mathrm{p}$.

7. Birley, S. (1989). Female entrepreneurs: are they really any different? Journal of Small Business Management, Vol. 27, Issue 1, 32-37.

8. Kourilsky, M.L., Walstad, W.B. (1998). Entrepreneurship and female youth: knowledge, attitudes, gender differences and educational practices. Journal of Business Venturing, Vol. 13, Issue $1,77-88$.

9. Kolvereid, L., Isaksen, E. (2006). New business start-up and subsequent entry into self-employment. Journal of Business Venturing, Vol. 21, Issue 6, 866-885. DOI: 10.1016/ j.jbusvent.2005.06.008.

10. Boisson, J.-P., Castagnos, J.-C., Deschamps, B. (2006). Motivations and drawbacks concerning entrepreneurial action: a study of French PhD students. International Entrepreneurship Education: Issues and Newness. Edited by A. Fayolle. Edward Elgar Publishing, 263-276. DOI: 10.4337/9781847201652.00022.

11. Liñán, F., Chen, Y.-W. (2007). Testing the Entrepreneurial Intention Model on a TwoCountry Sample. Documents de Treball, Departament d'Economia de l'Empresa, No. 7/06. Universitat Autònoma de Barcelona, $28 \mathrm{p}$.

12. Ruhle, S., Mühlbauer, D., Grünhagen, M., Rothenstein, J. (2010). The heirs of Schumpeter: an insight view of students' entrepreneurial intentions at the Schumpeter School of Business and Economics. Schumpeter Discussion Papers No. 2010-004. Wuppertal, University of Wuppertal, Schumpeter School of Business and Economics, $44 \mathrm{p}$.

13. Müller, S. (2008). Increasing entrepreneurial intention: effective entrepreneurship course characteristics. International Journal of Entrepreneurship and Small Business, Vol. 13, Issue 1, 55-74. DOI: 10.1504/IJESB.2011.040416.

14. Soetanto, D.P., Pribadi, H., Widyadana, G. A. (2010). Determinant factors of entrepreneurial intention among university students. IUP Journal of Entrepreneurship Development, Vol. 7, Issue $1 / 2,23-37$.

15. Bennett, R., Dann, S. (2000) The changing experience of Australian female entrepreneurs. Gender, Work \& Organization, Vol. 7, Issue 2, 75-83. DOI: 10.1111/1468-0432.00095.

16. Orhan, M. (2001). Women business owners in France: the Issue of financing discrimination. Journal of Small Business Management, Vol. 39, Issue 1, 95-102. DOI: 10.1111/04472778.00009 .

17. De Martino, R., Barbato, R. (2003). Differences between women and men MBA entrepreneurs: exploring family flexibility and wealth creation as career motivators. Journal of Business Venturing, Vol. 18, Issue 6, 815-832. DOI: 10.1016/S0883-9026(03)00003-X.

18. Bradley, F., Boles, K. (2003). Female Entrepreneurs from Ethnic Backgrounds: An Exploration of Motivations and Barriers. Manchester, Manchester Metropolitan University Business School.

19. Schwarz, E. J., Wdowiak, M. A., Almer-Jarz, D. A., Breitenecker, R. J. (2009). The effects of attitudes and perceived environment conditions on students' entrepreneurial intent: An Austrian perspective. Education and Training, Vol. 51, Issue 4, 272-291. DOI: 10.1108/00400910910964566.

20. Schoon, I., Duckworth, K. (2012). Who becomes an entrepreneur? Early life experiences as predictors of entrepreneurship. Developmental Psychology, Vol. 48, Issue 6, 1719-1726. DOI: $10.1037 / \mathrm{a} 0029168$.

21. Ruef, M., Aldrich, H.E., Carter, N. M. (2003). The structure of founding teams: Homophily, strong ties, and isolation among U.S. entrepreneurs. American Sociological Review, Vol. 68, Issue 2, 195-222. DOI: 10.1177/000312240406900208. 
22. Ajzen, I. (1991). The Theory of Planned Behaviour. Organizational Behavior and Human Decision Processes, Vol. 50, Issue 2, 179-211. DOI: 10.1016/0749-5978(91)90020-T.

23. Lakovela, T., Kolvereid, L., Stepen, U. (2011). Entrepreneurial intention in developed and developing countries. Education and Training, Vol. 53, Issue, 353-370. DOI: 10.1108/00400911111147686.

24. Kristiansen, S. Indarti, N. (2004). Entrepreneruial intention among Indonesian and Norwegian students. Journal of Enterprising Culture, Vol. 12, No. 1, 55-78. DOI: 10.1142/ S021849580400004X.

25. Tkachev, A., Kolvereid, L. (1999). Self-employment intentions among Russian students. Entrepreneurship \& Regional Development, Vol. 11, Issue 3, 269-280. DOI: 10.1080/089856299283209.

26. Autio, E., Keeley, R., Klofsten, M., Parker, G., Hay, M. (2001). Entrepreneurial Intent among Students in Scandinavia and in the USA. Enterprise and Innovation Management Studies, Vol. 2, Issue 2, 145-160. DOI: 10.1080/14632440110094632.

\section{INFORMATION ABOUT AUTHORS}

\section{Abid Ullah}

PhD, Department of Management Sciences, Ghulam Ishaq Khan Institute of Engineering Sciences and Technology, Topi Swabi, Pakistan (Topi Swabi KPK Pakistan, Khyber Pakhtunkhwa 23640, Pakistan); ORCID 0000-0003-1266-8924; e-mail: abidullah856@gmail.com.

\section{FOR CITATION}

Abid Ullah. Gender Asymmetry of Entrepreneurial Intentions of Students in Russia and China. Journal of Applied Economic Research, 2021, Vol. 20, No. 1, 133-147. DOI: 10.15826/ vestnik.2021.20.1.006.

\section{ARTICLE INFO}

Received October 15, 2020; Revised December 24, 2020; Accepted January 15, 2021. 


\title{
Гендерная асимметрия предпринимательских интенций студентов России и Китая
}

\author{
Абид Улла $\mathbb{D} \square$ \\ Институт инженерных наук и технологий им. Гулама Исхака Хана, \\ 2. Топи Сваби, Пакистан \\ \abidullah856@gmail.com
}

\begin{abstract}
Аннотоция. В современном мире предпринимательство рассматривается как важнейший инструмент решения проблемы трудоустройства молодых специалистов. Ситуация, в которой количество выпускников высших учебных заведений превышает количество потенциальных рабочих мест для них,- это не только стрессовый фактор для самих выпускников, но и серьезная нагрузка для политики, экономики страны в целом. Предпринимательская деятельность не только может облегчить возможную ситуацию с безработицей среди молодежи, но и способствовать экономическому развитию государства. Выбирая предпринимательскую деятельность, вчерашний выпускник не только начинает обеспечивать себя источником дохода, но и создает рабочие места для других людей, что благотворно влияет на экономику. В статье анализируется влияние гендерного фактора на предпринимательские интенции в молодежной среде стран с переходной экономикой - России и Китая. Выводы, приведенные в статье, основываются на данных опросников, распространенных между студентами, изучающими экономику и предпринимательство в 6 университетах (3 университета в Китае, 3 в России). В качестве инструмента статистического анализа данных в рамках данной статьи были использованы возможности программы Statistical Package for the Social Sciences. На платформе этой программы была проанализирована информация, полученная от 468 респондентов. Для поиска взаимосвязей переменных был проведен множественный регрессионный анализ и применялись корреляционные методы. Результаты исследования показали, что у студентов обеих стран обнаруживается взаимосвязь гендерного фактора и предпринимательских интенций. Однако в высших учебных заведениях России респонденты мужчины показали более высокий уровень предпринимательских интенций, чем женщины (в сравнении с результатами китайских респондентов). На основании проведенного анализа в статье сформулированы предложения для работников образовательной сферы, а также политиков.
\end{abstract}

Ключевые слово: предпринимательство; предпринимательские интенции в молодёжной среде; гендер; теория запланированного поведения.

\section{Список использованных источников}

1. Reynolds P., Hart M., Mickiewicz T. The UK Business Creation Process: The 2013 Panel Study of Entrepreneurial Dynamics Pretest // Foundations and Trends in Entrepreneurship. 2014. Vol. 4. Pp. 1-43. DOI: 10.13140/RG.2.2.27165.51685.

2. Haftendorn K., Salzano C. Facilitating Youth Entrepreneurship. Part 1: An Analysis of Awareness and Promotion Programmes in Formal and Non-formal Education // SEED Working Paper No. 59. Geneva, Switzerland: International Labour Office, 2003. 70 p.

3. Drucker P. Innovation and Entrepreneurship. Practice and Principles. London: Heinemann, 1985. $27 \mathrm{p}$. 
4. Thurik R., Wennekers S. Entrepreneurship, small business and economic growth // Journal of Small Business and Enterprise Development. 2004. Vol. 11, No. 1. Pp. 140-149. DOI: 10.1108/14626000410519173.

5. Baumol W. The Free-Market Innovation Machine. Princeton: Princeton University Press, 2002. 336 p.

6. Minniti M., Allen I. E., Langowitz N. Global Entrepreneurship Monitor 2005. Report on Women and Entrepreneurship. Babson Park: The Center for Women's Leadership at Babson College, 2005. 79 p.

7. Birley S. Female entrepreneurs: are they really any different? // Journal of Small Business Management. 1989. Vol. 27, Issue 1. Pp. 32-37.

8. Kourilsky M. L., Walstad W. B. Entrepreneurship and female youth: knowledge, attitudes, gender differences and educational practices // Journal of Business Venturing. 1998. Vol. 13, Issue 1. Pp. 77-88.

9. Kolvereid L., Isaksen E. New business start-up and subsequent entry into selfemployment // Journal of Business Venturing. 2006. Vol. 21, Issue 6. Pp. 866-885. DOI: 10.1016/ j.jbusvent.2005.06.008.

10. Boisson J.-P., Castagnos J.-C., Deschamps B. Motivations and drawbacks concerning entrepreneurial action: a study of French $\mathrm{PhD}$ students // International Entrepreneurship Education: Issues and Newness / Edited by A. Fayolle. Edward Elgar Publishing, 2006. Pp. $263-$ 276. DOI: $10.4337 / 9781847201652.00022$.

11. Liñán F., Chen Y.-W. Testing the Entrepreneurial Intention Model on a Two-Country Sample // Documents de Treball, Departament d'Economia de l'Empresa. No. 7/06. Universitat Autònoma de Barcelona, 2007. $28 \mathrm{p}$.

12. Ruhle S., Mühlbauer D., Grünhagen M., Rothenstein J. The heirs of Schumpeter: an insight view of students' entrepreneurial intentions at the Schumpeter School of Business and Economics // Schumpeter Discussion Papers No. 2010-004. Wuppertal: University of Wuppertal, Schumpeter School of Business and Economics, 2010. 44 p.

13. Müller $S$. Increasing entrepreneurial intention: effective entrepreneurship course characteristics // International Journal of Entrepreneurship and Small Business. 2008. Vol. 13, Issue 1. Pp. 55-74. DOI: 10.1504/IJESB.2011.040416.

14. Soetanto D. P., Pribadi H., Widyadana G. A. Determinant factors of entrepreneurial intention among university students // IUP Journal of Entrepreneurship Development. 2010. Vol. 7, Issue 1/2. Pp. 23-37.

15. Bennett R., Dann $S$. The changing experience of Australian female entrepreneurs // Gender, Work \& Organization. 2000. Vol. 7, Issue 2. Pp. 75-83. DOI: 10.1111/1468-0432.00095.

16. Orhan $M$. Women business owners in France: the Issue of financing discrimination // Journal of Small Business Management. 2001. Vol. 39, Issue 1. Pp. 95-102. DOI: 10.1111/04472778.00009 .

17. De Martino R., Barbato R. Differences between women and men MBA entrepreneurs: exploring family flexibility and wealth creation as career motivators // Journal of Business Venturing. 2003. Vol. 18, Issue 6. Pp. 815-832. DOI: 10.1016/S0883-9026(03)00003-X.

18. Bradley F., Boles K. Female Entrepreneurs from Ethnic Backgrounds: An Exploration of Motivations and Barriers. Manchester: Manchester Metropolitan University Business School, 2003.

19. Schwarz E. J., Wdowiak M. A., Almer-Jarz D. A., Breitenecker R. J. The effects of attitudes and perceived environment conditions on students' entrepreneurial intent: An Austrian perspective // Education and Training. 2009. Vol. 51, Issue 4. Pp. 272-291. DOI: 10.1108/00400910910964566.

20. Schoon I., Duckworth K. Who becomes an entrepreneur? Early life experiences as predictors of entrepreneurship // Developmental Psychology. 2012. Vol. 48, Issue 6. Pp. 17191726. DOI: $10.1037 / \mathrm{a} 0029168$. 
21. Ruef M., Aldrich H. E., Carter N. M. The structure of founding teams: Homophily, strong ties, and isolation among U.S. entrepreneurs // American Sociological Review. 2003. Vol. 68, Issue 2. Pp. 195-222. DOI: 10.1177/000312240406900208.

22. Ajzen I. The Theory of Planned Behaviour // Organizational Behavior and Human Decision Processes. 1991. Vol. 50, Issue 2. Pp. 179-211. DOI: 10.1016/0749-5978(91)90020-T.

23. Lakovela T., Kolvereid L., Stepen U. Entrepreneurial intention in developed and developing countries // Education and Training. 2011. Vol. 53, Issue. Pp. 353-370. DOI: 10.1108/00400911111147686.

24. Kristiansen $S$. Indarti N. Entrepreneruial intention among Indonesian and Norwegian students // Journal of Enterprising Culture. 2004. Vol. 12, No. 1. Pp. 55-78. DOI: 10.1142/ S021849580400004X.

25. Tkachev A., Kolvereid L. Self-employment intentions among Russian students // Entrepreneurship \& Regional Development. 1999. Vol. 11, Issue 3. Pp. 269-280. DOI: 10.1080/089856299283209.

26. Autio E., Keeley R., Klofsten M., Parker G., Hay M. Entrepreneurial Intent among Students in Scandinavia and in the USA // Enterprise and Innovation Management Studies. 2001. Vol. 2, Issue 2. Pp. 145-160. DOI: 10.1080/14632440110094632.

\section{ИНФОРМАЦИЯ ОБ АВТОРАХ}

\section{Абид Улла}

$\mathrm{PhD}$, Департамент менеджмента, Институт инженерных наук и технологий им. Гулама Исхака Хана, г. Топи Сваби, Пакистан (Топи Сваби, Хайбер-Пахтунхва 23640, Пакистан); ORCID 0000-0003-1266-8924; e-mail: abidullah856@gmail.com.

\section{ДЛЯ ЦИТИРОВАНИЯ}

Абид Улла. Гендерная асимметрия предпринимательских интенций студентов России и Китая // Journal of Applied Economic Research. 2021. Т. 20, № 1. C. 133-147. DOI: 10.15826/ vestnik.2021.20.1.006.

\section{ИНФОРМАЦИЯ О СТАТЬЕ}

Дата поступления 15 октября 2020 г.; дата поступления после рецензирования 24 декабря 2020 г.; дата принятия к печати 15 января 2021 г. 